\title{
PENINGKATAN HASIL BELAJAR OPERASI HITUNG BILANGAN BULAT MELALUI PEMBELAJARAN HOTS BERBASIS INQUIRY MENGGUNAKAN ELECTRICAL CHARGES
}

\author{
The Improvement of Learning Achievement on Integer \\ Through Inquiry-Based Higher Order Thinking Skill (HOTS) Using Electrical Charges.
}

Erni Dwi Endarwati

SD Negeri Paliyan IV, Corot, Karangduwet, Paliyan, Gunungkidul, D.I Yogyakarta, Kode Pos 55871

*)E-mail korespondensi: ernidwiendarwati@gmail.com

\begin{abstract}
This research aims to improve learning achievement on integer of $6^{\text {th }}$ grade students in SD Paliyan IV Gunungkidul through inquiry-based Higher Order Thinking Skill (HOTS) learning using electrical charges. The research was a Classroom Action Research study. The study was conducted in two cycles. This research was conducted in SD Paliyan IV Paliyan Gunungkidul in October 2019. The subjects were all students of $6^{\text {th }}$ grade consisting of 19 students. The data were collected using observation, paper and pencil tests, and documentation. The results revealed that inquiry-based HOTS learning using electrical charges could improve learning achievement on integer of $6^{\text {th }}$ grade students.
\end{abstract}

Keywords: electrical charges, HOTS learning, integer, inquiry, learning achievement

\begin{abstract}
ABSTRAK
Penelitian ini bertujuan untuk meningkatkan hasil belajar siswa kelas 6 SD Paliyan IV Gunungkidul melalui pembelajaran High Order Thinking Skill (HOTS) berbasis inkuiri menggunakan electrical charges. Penelitian ini merupakan Penelitian Tindakan Kelas. Penelitian dilakukan dalam dua siklus. Penelitian ini dilaksanakan di SD Paliyan IV Paliyan Gunungkidul pada bulan Oktober 2019. Subjek penelitian ini adalah seluruh siswa kelas 6 yang terdiri dari 19 siswa. Pengumpulan data dilakukan dengan observasi, tes kertas dan pensil, dan dokumentasi. Hasil penelitian menunjukkan bahwa pembelajaran HOTS berbasis inkuiri dengan menggunakan electrical charges dapat meningkatkan hasil belajar siswa kelas VI bilangan bulat.
\end{abstract}

Kata kunci: bilangan bulat, electrical charges, hasil belajar, inkuiri, pembelajaran HOTS

\section{PENDAHULUAN}

Pendidikan bertujuan untuk menjadikan seseorang berilmu, mempunyai keterampilan dan berkarakter. Ilmu merupakan bekal hidup yang utama. Seseorang yang berilmu akan mengamalkannya dalam bentuk keterampilan. Namun, ilmu dan keterampilan saja tidak cukup. Seseorang juga harus mempunyai karakter kepribadian yang baik. Ketiga hal tersebut akan bersinergi dalam kehidupan sehari-hari. Oleh karena itu harus dilakukan proses pendidikan bagi setiap orang.

Proses pendidikan dapat dilakukan di berbagai tempat, salah satunya adalah sekolah. Sekolah merupakan wahana untuk mendapatkan ilmu, keterampilan, dan pendidikan karakter. Sekolah Dasar (SD) merupakan tempat pendidikan formal yang pertama. Pada jenjang ini tahapan penanaman keilmuan yang berupa pengetahuan dan konsep dimulai. Dengan penanaman awal yang mendalam pada diri peserta didik akan menghasilkan keterampilan. Keterampilan itu akan digunakan dalam menjalani kehidupan sehari-hari untuk saat ini dan masa yang akan datang seiring dengan perkembangan zaman.

Pembelajaran yang dilakukan di kelas hendaknya harus dapat mengaktifkan peserta didik. Pembelajaran harus memberikan kesempatan peserta didik untuk mentransfer pengetahuan, berfikir kreatif dan kritis. Selain itu di dalam pembelajaran harus diintegrasikan pendidikan karakter dan keterampilan abad 21. Dengan demikian peserta didik akan memeroleh pengetahuan sendiri bukan sekedar informasi dari guru kelas tidak terkecuali dalam mata pelajaran matematika. 
Di SD kelas tinggi matematika merupakan muatan pelajaran yang diajarkan tersendiri. Matematika berisi tentang algoritma dan konsep-konsep yang harus dikuasai oleh peserta didik sehingga mendapatkan keterampilan matematika. Keterampilan matematika tersebut akan dapat digunakan oleh mereka dalam memecahkan masalah dalam kehidupan sehari-hari. Salah satu materi matematika yang harus dikuasai peserta didik di SD kelas tinggi adalah keterampilan operasi hitung bilangan bulat.

Konsep bilangan bulat di SD mulai diajarkan di kelas VI semester 1. Kompetensi Dasar (KD) yang terkait dengan bilangan bulat adalah KD 3.2 Menjelaskan dan melakukan operasi penjumlahan, pengurangan, perkalian, dan pembagian yang melibatkan bilangan bulat negatif serta 4.2 Menyelesaikan masalah yang berkaitan dengan operasi penjumlahan, pengurangan, perkalian, dan pembagian yang melibatkan bilangan bulat negatif dalam kehidupan sehari-hari.

Dari uraian di atas, tampak bahwa peserta didik kelas VI SD harus menguasai konsep tentang operasi hitung bilangan bulat dengan benar. Untuk itu, peserta didik harus memahami konsepnya terlebih dahulu untuk dapat melakukan operasi hitung yang melibatkan bilangan bulat dengan benar. Pada akhirnya, peserta didik akan dapat menyelesaikan masalah dalam kehidupan seharihari yang melibatkan operasi hitung bilangan bulat. Oleh karena itu, penanaman konsep bilangan bulat di SD haruslah dilakukan dengan sebaik-baiknya supaya dipahami dengan baik oleh peserta didik. Namun demikian, pada kenyaataanya masih banyak peserta didik di kelas VI SD Negeri Paliyan IV, Corot, Karangduwet, Paliyan, Gunungkidul, D.I Yogyakarta yang menemui kesulitan dalam mempelajari konsep bilangan bulat. Hal ini dibuktikan dengan masih rendahnya hasil belajar peserta didik. Dari 19 peserta didik kelas VI diketahui baru ada 7 yang bisa mencapai Kriteria Ketuntasan Minimal (KKM) sebesar 70.

Ada beberapa hal penyebab kesulitan belajar yang mengakibatkan rendahnya hasil belajar peserta didik. Penyebab tersebut diantaranya sarana belajar yang masih terbatas, belum digunakannya media pembelajaran dan guru belum melakukan pembelajaran yang mengaktifkan peserta didik. Selama ini guru lebih sering menggunakan metode ceramah, memberikan contoh, penugasan dan mencocokkan hasil kerja peserta didik. Peserta didik hanya menerima konsep tentang operasi hitung bilangan bulat dari guru sehingga banyak peserta didik yang belum memahami lebih dalam.

Dari permasalahan tersebut di atas, maka perlu dilakukan penelitian yang difokuskan pada peningkatkan hasil belajar operasi hitung bilangan bulat melalui pembelajaran HOTS berbasis inquiry menggunakan electrical charges pada peserta didik kelas VI SD Paliyan IV Kecamatan Paliyan Kabupaten Gunungkidul. Rumusan masalah yang diambil adalah bagaimana pembelajaran HOTS berbasis inquiry menggunakan electrical charges dapat meningkatkan hasil belajar operasi hitung bilangan bulat peserta didik kelas VI SD Paliyan IV Gunungkidul. Tujuan dari penelitian ini adalah untuk meningkatkan hasil belajar operasi hitung bilangan bulat melalui pembajaran HOTS berbasis inquiry menggunakan electrical charges.

Penelitian ini diharapkan bermanfaat untuk peserta didik, guru, dan sekolah. Untuk peserta didik akan memberikan pengalaman belajar yang baru, menjadikannya lebih aktif dan bersemangat pada saat belajar, dan hasil belajarnya meningkat. Untuk guru dapat dijadikan pertimbangan ketika membuat rencana pembelajaran, meningkatkan kreativitas guru, dan bahan pertimbangan untuk melakukan penelitian selanjutnya. Sementara untuk sekolah, adalah memberikan kontribusi mutu sekolah terutama dalam pembelajaran matematika.

\section{METODE}

Penelitian ini adalah penelitian tindakan kelas yang dilaksanakan pada bulan September November 2019 di SD Paliyan IV, Gunungkidul dalam dua siklus. Setiap siklus terdiri dari perencanaan, pelaksanaan dan observasi, serta refleksi. Subjek penelitian adalah peserta didik kelas VI yang berjumlah 19 peserta didik. 
Pada tahap awal, peneliti melakukan observasi untuk mengetahui gambaran cara mengajarkan operasi hitung bilangan bulat serta hasil belajar peserta didik pada materi tersebut. Setelah itu, peneliti mendiskusikan permasalahan yang ditemui dalam pembelajaran bersama kolaborator.

Setiap siklus terdiri dari 3 kali pembelajaran. Dalam setiap pembelajaran terdapat penyusunan Rencana Pelaksanaan Pembelajaran (RPP), pelaksanaan tindakan sesuai RPP, observasi terhadap pelaksanaan tindakan, refleksi sebagai pijakan dalam merancang perbaikan pada tindakan berikutnya.

Teknik yang digunakan untuk pengumpulan data yaitu observasi dengan catatan lapangan dan instrumen berupa checklist proses pembelajaran. Tes untuk hasil belajar peserta didik. Tes dilaksanakan pada setiap akhir siklus. Dokumentasi dilakukan dengan mencermati berbagai data yang berkaitan dengan penelitian termasuk di dalamnya gambar foto pada saat kegiatan pembelajaran berlangsung. Kriteria keberhasilan penelitian diukur dengan minimal $75 \%$ peserta didik mencapai KKM 70.

Data yang diperoleh berupa data kualitatif dan data kuantitatif. Data kualitatif diperoleh dari catatan lapangan, hasil observasi, dan dokumentasi, kemudian dideskripsikan berdasarkan aspek yang diamati diantaranya deskripsi pelaksanaan pembelajaran HOTS berbasis inquiry menggunakan electrical charges dan deskripsi perilaku peserta didik. Data kuantitatif diperoleh dari tes tertulis. Data kuantitatif dianalisis secara deskriptif kuantitatif dengan menghitung skor per peserta didik, rata-rata skor perolehan dan persentase kemudian dideskripsikan dan diambil kesimpulan berdasarkan kriteria yang ditentukan.

\section{HASIL DAN PEMBAHASAN}

Sebelum penelitian dilakukan perencanaan. Perencanaan meliputi pembuatan RPP berorientasi HOTS, Lembar Kegiatan Peserta didik (LKPD), menyediakan kancing merah dan putih untuk electrical charges, kisi-kisi dan soal tes akhir siklus dan menyusun checklist proses pembelajaran untuk memantau aktivitas guru dan peserta didik selama proses pembelajaran siklus I.

Operasi hitung bilangan bulat diajarkan melalui pembelajaran yang berorientasi HOTS. Proses pembelajaran yang dilakukan juga mengintegrasikan PPK dan keterampilan abad 21 serta menerapkan model pembelajaran yang sesuai. Model pembelajaran yang dipilih adalah inquiry learning.

Inquiry learning adalah model pembelajaran dengan beberapa tahapan. Tahapan tersebut antara lain: (1) merumuskan masalah, (2) mengajukan hipotesis, (3) mengumpulkan data, (4) menguji hipotesis berdasarkan data yang dikumpulkan, (5) membuat kesimpulan. Model ini dapat mengakomodir pendekatan saintifik yang disarankan pada kurikulum 2013.

Dalam pendekatan saintifik salah satu langkahnya adalah mengamati. Hal tersebut sesuai dengan tahapan inquiry yang berupa mengumpulkan data dan menguji hipotesis. Dalam hal ini digunakan electrical charges.

Pembelajaran berorientasi HOTS dilakukan pada setiap pertemuan. Pembelajaran HOTS mengandung unsur transfer knowledge, critical and creative thingking, dan problem solving. Dalam pelaksanaan pembelajaran juga diintegrasikan PPK dan keterampilan abad 21. Dalam penelitian ini unsur-unsur pembelajaran HOTS akan diberi tanda kurung untuk memudahkan pemahaman para pembaca.

Setiap pembelajaran diawali dengan berdoa (religius) dan menyayikan Lagu Kebangsaan Indonesia Raya (nasionalisme). Selanjutnya PPK diterapkan dalam kegiatan pembelajaran diantaranya: mengajukan hipotesis (mandiri dan integritas), belajar kelompok (gotong royong). Sementara untuk keterampilan abad 21 diterapkan saat peserta didik merumuskan masalah dan mengajukan hipotesis 
(critical and creative thingking), belajar kelompok (collaboration), dan saat diskusi serta melaporkan hasil kerja kelompok (communication).

Tindakan pada siklus I terdiri dari 3 kali pertemuan. Pertemuan pertama diisi dengan pengenalan bilangan bulat. Dalam tahapan orientasi masalah guru menunjukkan garis bilangan rumpang (transfer knowledge). Peserta didik kemudian menjawab pertanyaan guru tentang bilangan berapa yang ditempatkan pada bagian yang kosong (critical thinking dan communication).

Selanjutnya, pada tahap merumuskan masalah guru mengajukan pertanyaan bagaimana cara meletakkan bilangan pada garis bilangan. Peserta didik membuat hipotesis (critical thingking). Hal ini merupakan tahapan ketiga dari pembelajaran model inkuiri. Peserta didik menjawab cara meletakkan bilangan pada garis bilangan dengan berbagai macam jawaban kemudian mereka menuliskan cara yang diungkapkan/ menggambarkan garis bilangan sesuai dengan tebakannya (creative).

Guru menggambarkan garis bilangan yang lengkap untuk menambah pengetahuan peserta didik. Peserta didik mengamati garis bilangan yang digambar oleh guru (transfer knowledge). Peserta didik terlihat penasaran dengan tebakan (hipotesis) yang sudah mereka buat, salah atau benar.

Untuk dapat menyimpulkan benar atau tidaknya hipotesis yang sudah dibuat perlu sebuah percobaan untuk membuktikan. Guru menggambar garis bilangan rumpang di papan tulis. Peserta didik mengambil kartu angka yang ada di meja guru lalu secara bergantian menempelkan kartu angka pada garis bilangan yang rumpang (creative dan problem solving). Selanjutnya peserta didik membuat kesimpulan dengan bimbingan guru.

Pertemuan kedua, mempelajari tentang operasi hitung penjumlahan bilangan bulat. Kegiatan apersepsi diisi dengan mengaitkan pembelajaran pada pertemuan lalu, yaitu peserta didik diminta menyebutkan contoh bilangan bulat (critical thinking dan communication). Pada tahapan orientasi masalah guru memberikan permasalahan. Peserta didik diberikan sebuah masalah oleh guru yaitu "Untuk melihat terumbu karang seorang penyelam menyelam sedalam $4 \mathrm{~m}$. Akan tetapi ia belum bisa melihat terumbu karang sehingga ia harus menyelam lagi sedalam $6 \mathrm{~m}$. Berada pada kedalaman berapakah penyelam itu sekarang?. Peserta didik merumuskan masalah yaitu bagaimana cara kita mengetahui posisi akhir penyelam?". Peserta didik juga membuat hipotesis tentang posisi akhir penyelam itu (critical thinking).

Tahap selanjutnya adalah mengumpulkan informasi. Pada tahapan ini peserta didik duduk berkelompok dengan pembagian yang sama seperti pada pertemuan sebelumnya (collaboration). Setiap kelompok mendapatkan 1 set kancing warna merah dan 1 set kancing warna putih serta satu tatakan kertas. Peserta didik mendapatkan penjelasan dari guru bahwa untuk membuktikan tebakan mereka tentang posisi akhir penyelam akan digunakan peragaan kancing/electrical charges. Aturan penggunaan kancing adalah kancing warna merah untuk bilangan positif dan putih untuk bilangan negatif, bilangan 0 (nol) dilambangkan dengan sepasang kancing merah dan putih (transfer knowledge).

Kegiatan dilanjutkan dengan menguji hipotesis. Pada tahapan ini peserta didik menyusun kancing sesuai dengan tebakan mereka. Peserta didik mencoba operasi hitung penjumlahan dengan mengambil kancing yang sesuai dan menyusunnya. Selanjutnya, mereka menghitung jumlah kancing yang tersisa dan mengamati warna kancing yang tidak berpasangan. Peserta didik menemukan bahwa jumlah kancing yang tidak berpasangan merupakan hasil dari operasi hasil penjumlahan tersebut (critical thinking dan problem solving).

Tahapan terakhir dari pembelajaran HOTS berbasis inkuiri adalah menyimpulkan. Peserta didik menjawab pertanyaan guru tentang cara melakukan operasi hitung penjumlahan bilangan bulat. Guru dan peserta didik menyimpulkan tentang operasi penjumlahan bilangan bulat. 
Pertemuan ketiga peserta didik mempelajari tentang operasi pengurangan bilangan bulat. Pada tahapan orientasi masalah peserta didik mengamati tayangan video perjalan sebuah lift (transfer knowledge). Untuk selanjutnya, peserta didik menjawab pertanyaan guru tentang posisi awal dan akhir lift (critical thinking).

Tahap kedua adalah merumuskan masalah. Pada tahapan ini peserta didik menentukan hubungan antara posisi awal dan akhir lift dengan menebak operasi hitung yang digunakan. Lalu, peserta didik menjawab pertanyaan guru tentang bagaimana cara mengetahui berapa tingkat lift itu naik (critical thinking).

Selanjutnya, adalah tahapan menuliskan hipotesis. Peserta didik menjawab cara mengetahui posisi akhir lift dengan berbagai macam jawaban. Mereka menuliskan cara yang diungkapkan/menuliskan operasi hitungnya (creative). Beberapa hipotesis yang ditulis oleh peserta didik tampak pada gambar 5 berikut.

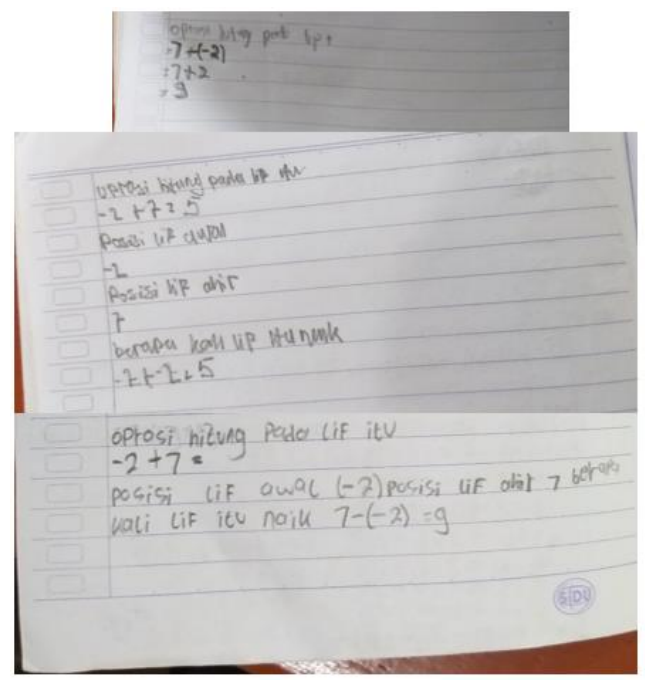

Gambar 5 Contoh hipotesis peserta didik

Hipotesis yang sudah dibuat diuji dengan melakukan operasi hitung pengurangan menggunakan electrical charges. Mereka menghitung jumlah kancing yang tidak berpasangan dan mengamati warnanya. Mereka menemukan bahwa jumlah kancing yang tidak berpasangan merupakan hasil. Selanjutnya, menulis operasi hitung yang telah mereka lakukan dengan lengkap di buku tulis masing-masing (problem solving dan critical thinking).

Untuk memantapkan temuan, peserta didik mengulangi percobaan melalui LKPD. Setiap kelompok mengambil 1 LKPD yang ada di meja guru. Peserta didik melakukan operasi hitung pengurangan bilangan bulat menggunakan electrical charges sesuai dengan soal yang mereka dapatkan (problem solving dan transfer knowledge). Peserta didik membacakan hasil kerja kelompok dan satu orang lainnya menuliskan di papan tulis. Peserta didik mengamati hasil kerja setiap kelompok. Bilangan kedua pada penjumlahan dan bilangan kedua pada pengurangan disebut bilangan yang saling berlawanan. Dengan demikian pengurangan bilangan bulat berarti menjumlahkan dengan lawan dari pengurangnya.

Pada akhir siklus I dilakukan evaluasi. Peserta didik yang tuntas dengan Kriteria Ketuntasan Minimal (KKM) 70 sebanyak 13 orang. Hal ini menunjukkan adanya peningkatan hasil belajar peserta didik. Namun, ada beberapa kendala yang dihadapi pada tindakan siklus I yaitu peserta didik merasa direpotkan dengan tatakan kertas saat sedang menguji hipotesis menggunakan electrical charges. Peserta didik memilih untuk tidak menggunanakannya lagi. Selain itu pembentukan kelompok belum sesuai sehingga harus dibentuk kelompok baru. Hasil refleksi 
tersebut digunakan untuk perbaikan di siklus II.

Siklus II terdiri dari 3 kali pertemuan. Pertemuan pertama mempelajari tentang operasi hitung perkalian bilangan bulat. Pada tahap apersepsi peserta didik sudah terlihat antusias. Hal ini terlihat pada saat mereka menjawab pertanyaan dari guru yang mengaitkan dengan materi pada pertemuan lalu yaitu operasi hitung penjumlahan dan invers bilangan bulat (communication).

Kegiatan inti pembelajaran diawali dengan orientasi masalah. Peserta didik diberikan sebuah masalah oleh guru yaitu "Suhu di Kota Paris pada pukul 06.00 adalah $-2^{\circ} \mathrm{C}$. Saat hari semakin siang, suhu naik $2^{\circ} \mathrm{C}$ setiap 2 jam sampai pukul 12.00. Berapa kenaikan suhu di kota itu? Peserta didik mengemukakan cara menyelesaikannya dengan berbagai jawaban (critical thinking dan communication). Peserta didik bertanya-tanya tentang bagaimana cara mengetahui kenaikan suhu yang terjadi. Hal itu merupakan tahapan kedua dari pembelajaran inkuiri yaitu merumuskan masalah.

Selanjutnya, peserta didik membuat hipotesis tentang besar kenaikan suhu dan cara menghitungnya (critical thinking). Guru mengarahkan supaya peserta didik menuliskan cara yang diungkapkan/menuliskan operasi hitungnya pada buku masing-masing (creative). Namun, sebelumnya peserta didik dibentuk dalam kelompok. Pada siklus II, penentuan kelompok dilakukan oleh guru supaya anggotanya lebih homogen. Kelompok yang terbentuk sebanyak 5. Masingmasing kelompok beranggotakan 4 orang. Setiap kelompok diberi nama. Nama yang diberikan berupa karakter yang diterapkan dalam PPK yaitu religius, nasionalisme, gotong royong, mandiri, dan integritas. Peserta didik terlihat senang dengan kelompok yang baru.

Kegiatan mengumpulkan informasi dimulai ketika peserta didik sudah duduk sesuai dengan kelompoknya. Setiap kelompok mengambil 1 set kancing merah dan 1 set kancing putih (electrical charges). Peserta didik mendengarkan penjelasan guru tentang aturan menggunakan kancing. Pada pertemuan ini tatakan kertas tidak digunakan lagi karena merepotkan peserta didik sehingga mereka menyusun kancing langsung di atas meja.

Tahapan terpenting dalam pembelaran inkuiri adalah menguji hipotesis. Peserta didik mencoba operasi hitung perkalian dengan mengambil kancing yang sesuai. Selanjutnya menghitung jumlah kancing yang tidak berpasangan dan mengamati warnanya. Mereka menemukan bahwa jumlah kancing yang tidak berpasangan merupakan hasil (transfer knowledge dan problem solving). Selanjutnya, mereka menulis operasi hitung yang telah mereka lakukan dengan lengkap di buku tulis masing-masing (creative). Setelah itu, guru membimbing peserta didik untuk mengambil kesimpulan tentang operasi hitung perkalian bilangan bulat (critical thinking dan communication).

Pada pertemuan kedua materi yang dipelajari adalah operasi hitung pembagian bilangan bulat. Pada kegiatan apersepsi peserta didik menjawab pertanyaan yang diajukan oleh guru antara tentang operasi hitung pengurangan dan invers bilangan bulat (communication). Hal tersebut merupakan kompetensi awal sebelum mereka mempelajari tentang operasi hitung pembagian.

Tahapan inkuiri yang berupa orientasi masalah diawali dengan pengamatan gambar dan pemberian masalah oleh guru. Masalah yang diberikan adalah "Ibu guru mempunyai permen sebanyak 20. Beliau akan memberikannya pada 5 murid dengan jumlah sama. Berapa permen yang diperoleh setiap murid? Peserta didik sangat antusias dalam mengemukakan cara menyelesaikannya. Hal ini terlihat dari berbagai jawaban yang mereka kemukakan (critical thinking dan communication). Selanjutnya, mereka diarahkan untuk merumuskan masalah "Bagaimana cara kita mengetahui jumlah permen yang diperoleh oleh setiap anak?".

Setelah merumuskan masalah, peserta didik diminta untuk membuat dugaan hasil dan cara menghitungnya. Hal ini adalah tahapan inkuiri yang berupa mengajukan hipotesis. Peserta didik menuliskan cara yang diungkapkan/menuliskan operasi hitungnya (creative). 
Pada saat menguji hipotesis, peserta didik terlihat antusias. Mereka berusaha untuk membuktikan dugaannya. Ada beberapa kelompok yang meminta bimbingan pada guru. Peserta didik menyusun kancing sesuai dengan tebakan mereka (Creative). Sebagian besar peserta didik menyusun kancing di atas meja, ada juga yang menyusunnya di atas buku. Peserta didik menulis operasi hitung yang telah mereka lakukan dengan lengkap di buku tulis masing-masing (creative).

Untuk menambah pengalaman dan transfer knowledge, peserta didik melakukan kegiatan berdasarkan pada LKPD yang dibuat oleh guru. Setiap kelompok mengambil 1 LKPD. LKPD tersebut berisi tentang operasi hitung pembagian bilangan bulat. Peserta didik menggambarkan susunan kancing pada buku masing-masing (creative). Masing-masing kelompok melakukan presentasi hasil kerja kelompok di depan kelas (communication). Peserta didik mengamati hasil kerja kelompok lain. Guru memberikan pertanyaan tentang bagaimana pembagian bilangan bulat positif dengan positif, positif dengan negatif, dan negatif dengan negatif. Selanjutnya, guru memberi kesempatan kepada peserta didik untuk menanggapi hasil kerja kelompok lain (critical thinking dan communication). Peserta didik diberi penguatan oleh guru tentang operasi pembagian bilangan bulat positif dan negatif (transfer knowledge). Di akhir pembelajaran guru dan peserta didik membuat kesimpulan.

Pertemuan ketiga mempelajari tentang hitung campuran bilangan bulat. Kegiatan inti pembelajaran dimulai dengan orientasi masalah. Peserta didik menyimak ilustrasi yang dibacakan oleh guru "Mirza sedang mengikuti lomba matematika. Ia berhasil menjawab 38 soal. Jawaban benar diberi skor 2 sedangkan jawaban salah diberi skor -1. Jika ia menjawab benar sebanyak 33 soal. Berapa nilai yang ia peroleh?". Peserta didik terlihat bersemangat dan termotivasi untuk mengikuti pembelajaran. Hal ini terlihat dari wajah peserta didik saat berpikir. Mereka menjawab pertanyaan guru tentang berapa skor untuk jawaban benar dan berapa skor untuk jawaban salah? (critical thinking dan communication). Selanjutnya, mereka merumuskan masalah bagaimana caranya mengetahui skor akhir Mirza.

Selanjutnya, peserta didik mengajukan hipotesis. Peserta didik menjawab cara mengetahui skor akhir Mirza dengan berbagai macam jawaban (critical thinking). Peserta didik menuliskan cara yang diungkapkan/menuliskan operasi hitungnya (creative). Mereka terlihat senang karena bisa membuat dugaan sementara. Selanjutnya, mereka melakukan percobaan dengan electrical charges. Masing-masing kelompok melakukan presentasi hasil kerja kelompok di depan kelas (communication). Peserta didik membuat kesimpulan tentang kegiatan hari ini dengan bimbingan guru (literasi).

Evaluasi akhir siklus dilakukan setelah semua rangkaian pembelajaran dilakukan. Hasil tes menunjukkan peserta didik yang dapat mencapai KKM sebanyak 15 orang atau $79 \%$. Dengan demikian dapat dikatakan bahwa hasil belajar peserta didik pada setiap siklus mengalami peningkatan. Hal ini dibuktikan dengan meningkatnya persentase peserta didik yang mencapai KKM seperti tersaji pada tabel 1 berikut:

Tabel 1 Peningkatan jumlah peserta didik mencapai KKM

\begin{tabular}{ccc}
\hline Pra Tindakan & Siklus I & Siklus II \\
\hline 7 orang & 13 orang & 15 orang \\
$(47 \%)$ & $(68 \%)$ & $(79 \%)$ \\
\hline
\end{tabular}

Dari tabel di atas diketahui bahwa pada pra tindakan jumlah peserta didik yang mencapai KKM sebanyak 7 orang. Jumlah tersebut meningkat pada akhir siklus I menjadi 13 orang dan pada akhir siklus II naik menjadi 15 orang. Dengan demikian, hasil belajar peserta didik meningkat setelah dilakukan pembelajaran HOTS berbasis inquiry menggunakan electrical charges. 
Pembelajaran HOTS adalah pembelajaran yang memfasilitasi peserta didik untuk mendapatkan kesempatan untuk transfer knowledge dan mengembangkan keterampilan berpikir. Keterampilan berpikir yang dimaksud berkaitan dengan ranah kognitif, afektif dan psikomotor. Unsur utama dari pembelajaran HOTS adalah transfer knowledge, critical and creative thinking dan problem solving.

Pembelajaran HOTS juga mengintegrasikan PPK dan keterampilan abad 21. PPK diintegrasikan dalam proses pembelajaran untuk membentuk karakter yang baik bagi peserta didik. Karakter tersebut diantaranya: religius, nasionalisme, gotong royong, mandiri dan integritas. Sedangkan keterampilan abad 21 diintegrasikan dalam pembelajaran HOTS dalam rangka mempersiapkan peserta didik menghadapi kehidupan di masa globalisasi yang akan datang. Keterampilan tersebut meliputi: kritis, kreatif, kolaborasi dan komunikasi.

Peserta didik yang mempunyai karakter baik akan terlihat saat proses pembelajaran. Mereka mampu bekerja sama dengan temannya di dalam kelompok. Mereka juga teliti terhadap apa yang mereka lakukan serta percaya diri dalam melakukan pembelajaran dan menyampaikan hasil kerjanya. Karakter ini mempengaruhi hasil belajar yang diperoleh.

Secara umum hasil belajar peserta didik mengalamai peningkatan setelah dilakukan pembelajaran HOTS berbasis inquiry menggunakan electrical charges. Saat pembelajaran peserta didik mendapat kesempatan untuk mentransfer pengetahuan dari berbagai macam kegiatan yang disesuaikan dengan sintak pembelajaran inkuiri. Kegiatan tersebut diantaranya mendengarkan penjelasan guru tentang penggunaan electrical charges, melakukan percobaan saat membuktikan hipotesis, dan mengamati hasil percobaan.

Peserta didik juga mendapat kesempatan untuk berpikir kritis dan kreatif. Hal tersebut dilakukan pada tahapan inkuiri yang berupa merumuskan masalah, membuat hipotesis. Hal lain yang memerlukan kemampuan berpikir kritis adalah saat menanggapi hasil kerja kelompok lain. Sementara untuk kreatifitas ditunjukkan peserta didik saat menyusun kancing 2 warna sebagai operasi hitung bilangan bulat.

Pada pembelajaran HOTS berbasis inkuiri dimulai dari orientasi masalah. Peserta didik berusaha mencari rumusan masalahnya dan memecahkan atau mencari jawaban dari masalah tersebut. Peserta didik melakukan percobaan menyusun kancing 2 warna (electrical charges) untuk menguji hipotesis dan melatih kemampuan problem solving peserta didik. Hal tersebut sesuai dengan pendapat Afandi \& Sajidan (2017:34) bahwa pembelajaran HOTS melibatkan 3 aspek keterampilan. Keterampilan tersebut yaitu: transfer of knowledge, critical and creative thinking, dan problem solving.

Proses pembelajaran yang mengalami peningkatan kualitas mempengaruhi adanya peningkatan hasil belajar. Peserta didik antusias mengikuti pembelajaran HOTS berbasis inquiry menggunakan electrical charges di setiap pertemuan sehingga terjadi peningkatan hasil belajar.

Kenaikan rata-rata kelas diperoleh setelah pembelajaran HOTS berbasis inquiry menggunakan electrical charges. Peserta didik mendapatkan pengalaman belajar dan pemahaman yang lebih konkret. Hal tersebut sesuai dengan karakteristik peserta didik kelas VI SD dimana tahap perkembangannya berada pada tahap operasional konkret (Piaget, dalam Schunk 2010). Dalam tahap ini taraf berfikir peserta didik didasarkan pada manipulasi objek konkret berupa kancing 2 warna.

Electrical Charges merupakan model yang digunakan untuk meningkatkan kemampuan operasi hitung bilangan bulat. Hal ini senada dengan penelitian Muginah dan Djamilah Bondan Widjajanti (2014) penggunaan model Electrical Charges dapat meningkatkan keterampilan operasi hitung bilangan bulat. 
Pembelajaran yang dirancang berorientasi HOTS berbasis inquiry. Peserta didik melakukan langkah-langkah sesuai dengan sintak inkuiri diantaranya orientasi masalah, merumuskan masalah, membuat hipotesis, mengumpulkan informasi, menguji hipotesis dan menyimpulkan.

Pada saat menguji hipotesis peserta didik melakukan percobaan menggunakan kancing 2 warna (electrical charges) secara langsung untuk mempelajari operasi hitung bilangan bulat. Peserta didik melakukan operasi hitung dan menuliskan pada LKPD. Selanjutnya, peserta didik mendiskusikan hasil pekerjaan tersebut bersama teman sekelompoknya untuk mendapatkan kesimpulan. Dengan demikian peserta didik memperoleh pengalaman matematika yang mendalam. Hal ini sesuai dengan Penelitian yang dilakukan oleh Husna Nur Dini (2018) bahwa pembelajaran HOTS erat kaitannya dengan literasi matematika.

Pengalaman belajar menggunakan pembelajaran HOTS berbasis inquiry membuat peserta didik lebih memahami materi sehingga dapat mengerjakan tes dengan baik. Senada dengan hasil penelitian Roida Eva Flora Siagian Dan Maya Nurfitriyanti (2019) bahwa inquiry berpengaruh positif terhadap hasil belajar peserta didik.

\section{KESIMPULAN DAN SARAN.}

Berdasarkan hasil penelitian, refleksi dan pembahasan, maka dapat diambil kesimpulan. Kesimpulan tersebut adalah terjadinya peningkatan hasil belajar operasi hitung bilangan bulat pada peserta didik kelas VI setelah dilakukan pembelajaran HOTS berbasis inquiry menggunakan electrical charges. Dengan demikian penelitian ini dikatakan berhasil.

Bukti keberhasilan penelitian ini ditunjukkan dengan tercapainya kriteria keberhasilan penelitian yaitu minimal $75 \%$ peserta didik mencapai nilai KKM. Peningkatan capaian KKM terus meningkat, pada pra siklus peserta didik yang mencapai KKM hanya $47 \%$, siklus I meningkat menjadi 68\%, dan pada siklus II mencapai 79\%. Pembelajaran HOTS berbasis inquiry menggunakan electrical charges menjadikan peserta didik belajar dengan aktif sekaligus mengintegrasikan PPK dan keterampilan Abad 21.

\section{DAFTAR PUSTAKA}

Afandi \& Sajidan. (2017). Stimulasi Keterampilan Tingkat Tinggi. UNSPRESS.

Anderson, L.W \& Krathwohl, D.R. (2015). Kerangka Landasan Untuk Pembelajaran, Pengajaran, dan Asesmen. (Terjemahan Agung Prihantoro). Upper Saddle River: Pearson. (Buku asli diterbitkan tahun 2001)

Bennet, A.B.Jr., Burton, L.J, \& Nelson, L.T. (2010). Mathematics For Elementary Teachers A Conceptual Approach. New York: McGraw-Hill.

Briggs, M., Woodfield, A., Martin, C., \& Swatton, P. (2009). Assessment For Learning and Teaching In Primary Schools $\left(2^{\text {nd }} \mathrm{ed}\right.$ ). Exeter: Learning Matters Ltd

Forbes, J.E \& Eicholz R.E. (1971). Mathematics For Elementary Teachers. Manila: Addision-Wesley Publishing Company Inc

Hanafiah, Nanang. dan Cucu, Suhana. 2009. Konsep Strategi Pembelajaran. PT Refika Aditama. Bandung.

Heruman. (2012). Model Pembelajaran Matematika Di Sekolah Dasar. Bandung: Remaja Rosdakarya.

Husna Nur Dinni. (2018). HOTS (High Order Thinking Skills) dan Kaitannya dengan Kemampuan Literasi Matematika. PRISMA Prosiding Seminar Nasional Matematika Pg. 107-176

Immergut, B.E.D \& Smith, J.R. (2005). Arithmetic and Algebra $\left(2^{\text {nd }} e d\right)$. New York: 
McGraw-Hill.

Muginah \& Djamilah Bondan Widjajanti. (2014). Peningkatan Keterampilan Hitung Bilangan Bulat Melalui Metode Electrical Charges Pada Peserta didik Kelas V SD. Jurnal Prima Edukasia, Volume 2 - Nomor 2, 2014.

Phye, G. D. (2001). Handsbook Of Classroom Assesment Learning, Adjusment, and Achievment. San Diego: Academic Press Inc

Roida E.F.S. \& Maya N. (2018). Metode Pembelajaran Inquiry dan Pengaruhnya Terhadap Hasil Belajar Matematika Ditinjau Dari Kreativitas Belajar. Jurnal Formatif 2(1): 3544

Schunk, D. H., Pintrich, P. R., dan Meece, J. L. (2010). Motivation In Education Theory, Research, and Applications. Upper Saddle River: Pearson

Udin Syaefudin Sa'ud. (2008). Inovasi Pendidikan. Bandung: Alfabeta.

Yoki Ariyana. (2019). Buku Pegangan Pembelajaran Berorientasi pada Keterampilan Berpikir Tingkat Tinggi. Jakarta: Kementerian Pendidikan dan Kebudayaan 